\title{
PENGGUNAAN GOOGLE FORM DALAM MENINGKATKAN EFEKTIVITAS EVALUASI PEMBELAJARAN DARING SISWA PADA MASA COVID19 DI SD IT BAITUL MUSLIM WAY JEPARA
}

\begin{tabular}{|c|c|c|}
\hline \multicolumn{3}{|c|}{$\begin{array}{c}\text { Siti Ngafifah } \\
\frac{\text { sitingafifah57@gmail.com }}{\text { STIS Darul Ulum }}\end{array}$} \\
\hline $\begin{array}{l}\text { Received: } \\
\text { 02/12/2020 }\end{array}$ & $\begin{array}{c}\text { Revised: } \\
\text { 05/12/2020 }\end{array}$ & $\begin{array}{l}\text { Aproved: } \\
\text { 13/12/2020 }\end{array}$ \\
\hline
\end{tabular}

\begin{abstract}
This article aims to determine the advantages and disadvantages of using Google Forms in evaluating student online learning during the Covid19 pandemic at SD IT Baitul Muslim Way Jepara, East Lampung. This study uses qualitative methods and data collection techniques using observation, interviews, and documentation. The learning process at SD IT Baitul Muslim was carried out using Whatsapp, Zoom, and cellphone media. However, when the learning evaluation arrives, both the daily, mid-semester, and end-semester evaluations of SD IT BM use Google Form because the application from Google is very easily accessible to anyone provided they have a gmail.com account. The results showed that the learning evaluation using Google Form implemented by SD IT Baitul Muslim Way Jepara East Lampung was less effective. Due to feature limitations, design, and lack of editing history. In the realm of assessment, teachers are expected to not only refer to one type of Learning Evaluation but need to apply assessment (evaluation), namely continuity, objectivity, comprehensive, practical and cooperative which aims to optimize the ongoing learning. The positive contribution of this article is expected to provide information to education actors to improve skills and integrity in various learning activities in general, as well as in distance learning (online) specifically to facilitate the learning evaluation process during the current Covid19 pandemic.
\end{abstract}

Keywords: Google Forms, Evaluation, Learning, Covid19

\begin{abstract}
Abstrak
Artikel ini bertujuan untuk mengetahui kelebihan dan kekurangan penggunaan Google form dalam evaluasi pembelajaran online siswa pada masa pandemi Covid19 di SD IT Baitul Muslim Way Jepara Lampung Timur. Penelitian ini menggunakan metode kualitatif serta teknik pengumpulan datanya menggunakan observasi, wawancara, dan
\end{abstract}


dokumentasi. Proses pembelajaran di SD IT Baitul Muslim dilakukan dengan media Whatsapp, Zoom, dan Telepon seluler. Namun saat evaluasi pembelajaran tiba baik evaluasi harian, tengah semester, dan akhir semester SD IT BM menggunakan Google Form dikarenakan aplikasi dari Google tersebut sangat mudah diakses oleh siapapun dengan syarat memiliki akun gmail.com. Hasil penelitian menunjukkan bahwa evaluasi pembelajaran menggunakan Google Form yang dilaksanakan oleh SD IT Baitul Muslim Way Jepara Lampung Timur kurang efektif. Karena keterbatasan fitur, desain, dan kurangnya riwayat pengeditan. Pada ranah penilaian, guru diharapkan tidak hanya mengacu pada satu jenis Evaluasi Pembelajaran tetapi perlu menerapkan penilaian (evaluasi) yaitu kontinuitas, objektivitas, komprehensif, praktis dan kooperatif yang bertujuan untuk mengoptimalkan pembelajaran yang berlangsung. Kontribusi positif dari artikel ini diharapkan dapat memberikan informasi kepada para pelaku pendidikan guna meningkatan keterampilan dan integritas di berbagai aktivitas pembelajaran secara umum, serta di dalam pembelajaran jarak jauh (Daring) secara khusus guna memudahkan dalam proses evaluasi pembelajaran pada masa pendemic covid19 saat ini.

\section{Kata Kunci: Google Formulir, Evaluasi, Pembelajaran, Covid19}

\section{A. Pendahuluan}

Pada masa pendemi covid19, Indonesia melakukan upaya untuk memutus rantai penyebaran Covid19 dengan melakukan inovasi baru baik dalam bidang ekonomi, social, pendidikan, kesehatan dan keamanan. ${ }^{1}$ Diantara upaya tersebut salah satunya adalah dengan pemerintah mewajibkan untuk WFH (work from home), SFH (study from home). Menteri pendidikan Nadiem Makarim melakukan sebuah upaya bagi seluruh lembaga pendidikan untuk melakukan pembelajaran jarak jauh (Daring). ${ }^{2}$ Menurut hasil penelitian Indonesia merupakan Negara dengan pengguna internet kelima terbesar di dunia. Berdasarkan data balai statistic Indonesia, terdapat 50\% dari keseluruhan penduduk Indonesia sekitar 132.000

\footnotetext{
${ }^{1}$ Ita Ainun Jariyah and Esti Tyastirin, "Proses dan Kendala Pembelajaran Biologi di Masa Pandemi Covid-19: Analisis Respon Mahasiswa,” Jurnal Penelitian dan Pengkajian Ilmu Pendidikan: e-Saintika 4, no. 2 (July 8, 2020): 183, https://doi.org/10.36312/e-saintika.v4i2.224.

2 asrilia Kurniasari, Fitroh Setyo Putro Pribowo, And Deni Adi Putra, "Analisis Efektivitas Pelaksanaan Belajar Dari Rumah (BDR) Selama Pandemi Covid-19” 6, no. 3 (2020): 8.
} 
pengguna internet yang mayoritas penggunanya adalah para pelajar. ${ }^{3}$

Melihat keadaan Indonesia saat ini, yang merupakan Negara dengan kasus covid19 terbanyak di Asia Tenggara. Sejak bulan Maret 2020 secara nasional kegiatan belajar siswa di lakukan di rumah di karenakan semakin meningkat per 20 Juli 2020 mencapai 43.803 kasus dan terus meningkat. ${ }^{4}$ Maka Langkah yang paling tepat adalah dengan menetapkan bahwa proses pembelajaran dilakukan jarak jauh. ${ }^{5}$ Tidak hanya di Indonesia saja yang melakukan pembelajaran jarak jauh, akan tetapi seluruh dunia sedang menerapkan system pembelajaran tersebut. Dalam keadaan normal pun banyak terjadinya tumpang tindih dalam pembelajaran di berbagai daerah. Kementrian pendidikan dibawah kepemimpinan Menteri Pendidikan Nadiem Makarim, mendemonstrasikan semangat peningkatan produktivitas bagi siswa untuk mengangkat peluang kerja ketika menjadi lulusan sekolah. Dengan adanya covid19 yang mendadak maka dunia pendidikan perlu mengikuti alur yang dapat menolong kondisi sekolah dalam keadaan darurat yang mana sekolah perlu memaksakan diri menggunakan daring. ${ }^{6}$

Upaya sekolah dalam mengikuti aturan dari KemenDikBud diantara banyaknya instansi pendidikan di Indonesia yang melakukan pembelajaran jarak jauh salah satunya ialah Sekolah Dasar Islam Terpadu (SD IT) Baitul Muslim guna mendukung terlaksananya proses belajar dan mengajar di masa saat ini. Penggunaan pembelajaran jarak jauh (Daring) di Sekolah Dasar Islam Terpadu (SD IT) Baitul Muslim Way Jepara pada masa pandemic covid19, seluruh Tenaga pendidik diwajibkan untuk menggunakan pembelajaran berbasis teknologi. Dengan menerapkan penggunaan Google form dalam evaluasi pembelajaran, yang bertujuan untuk tetap melakukan pembelajaran dengan tidak menghadirkan siswa

3 Neng Marline Efendi.”pendidikan, sosiologi, dan antropologi UGM.”Revolusi pembelajaran berbasis digital.2 no.2 (2018).2

${ }^{4}$ Desrina Yusi Irawati and Jonatan Jonatan, "Evaluasi Kualitas Pembelajaran Online Selama Pandemi Covid-19: Studi Kasus di Fakultas Teknik, Universitas Katolik Darma Cendika,” Jurnal Rekayasa Sistem Industri 9, no. 2 (July 27, 2020): 135-44, https://doi.org/10.26593/jrsi.v9i2.4014.135-144.

${ }^{5}$ Riskey Oktavian and Riantina Fitra Aldya, "Efektivitas Pembelajaran Daring Terintegrasi di Era Pendidikan 4.0,” Didaktis: Jurnal Pendidikan dan Ilmu Pengetahuan 20, no. 2 (May 12, 2020), https://doi.org/10.30651/didaktis.v20i2.4763.

${ }^{6}$ Rizqon Halal Syah Aji. “jurnal social dan budaya syar-I FSH UIN syarif hidayatullah Jakarta.”Dampak covid-19 pada pendidikan di Indonesia. 7 No.5(2020).1 
ke sekolah sehingga terjadi berkumpulnya siswa karena dikhawatirkan akan mengakibatkan bertambahnya korban pandemic covid19. Tujuan diberlakukanya pembelajaran jarak jauh adalah untuk memutus mata rantai covid19. Hal ini tentu menarik untuk diteliti lebih jauh penggunaan google from yang digunakan sebagai media evaluasi pembelajaran.

\section{B. Pembahasan}

\section{Penggunaan Google form}

Aplikasi Google form merupakan salah satu layanan dari Google docs. aplikasi ini memiliki ruang untuk membuat kuis, survey online dan formulir yang didukung dengan banyaknya aksesbilitas yaitu hanya dapat dibaca saja (reading) dan juga untuk mengedit dokumen (editing). Seorang guru yang akan melakukan pengevaluasian pembelajaran maka syarat untuk membuat Google form adalah pertama seorang guru wajib memiliki akun Google terlebih dahulu dengan mendaftar di http://account.Google.com/login. ${ }^{7}$

Setelah memiliki akun Google maka selanjutnya adalah memilih fitur yang sudah disediakan oleh Google berupa Gmail,Google form,Google Drive, Youtube, Google play, diantara fitur tersebut memiliki kegunaan yang berbedabeda. Seperti Gmail sebagai alat kominukasi dengan menggunakan Email, Google drive sebagai alat penyimpanan secara online, Youtube sebagai menyimpan dan berbagi video secara online, Google play sebagai berbagi aplikasi. $^{8}$

Disisi lain Google form memiliki kelebihan didalam dunia pendidikan yaitu 1.) guru dapat membuat soal latihan harian/ ulangan per bab. 2.) dapat mengumpulkan angket dengan memberikan alamat website. 3.) untuk mengumpulkan data guru dan murid dalam waktu yang singkat. 4.) membuat formulir pendaftaran dengan secara online tanpa harus datang ke tempat

7 Sri Bulan and Husniyatus Salamah Zainiyati, "Pembelajaran Online Berbasis Media Google Formulir dalam Tanggap Work From Home Masa Pandemi Covid-19 di Madrasah Ibtidaiyah Negeri (MIN) 1 Paser," SYAMIL: Jurnal Pendidikan Agama Islam (Journal of Islamic Education) 8, no. 1 (June 10, 2020): 15-34, https://doi.org/10.21093/sy.v8i1.2300.

${ }^{8}$ Hamdan Husein Batubara, "Penggunaan Google Form Sebagai Alat Penilaian Kinerja Dosen Di Prodi Pgmi Uniska Muhammad Arsyad Al Banjari,” n.d., 12. 
sekretariat sekolah. ${ }^{9}$

Dengan begitu dalam upaya pencegahan penyebaran wabah covid19 maka Google form sangat membantu dalam proses evaluasi pembelajaran sekolah dimasa saat ini. Hal ini sesuai dengan menteri Pendidikan dan kebudayaan Republik Indonesia terkait surat edaran Nomor 4 Tahun 2020 tentang pelaksanaan Kebijakan Pendidikan dalam masa Darurat Penyebaran Corona Virus Disease (COVID19). Sistem pembelajaran dilaksanakan melalui perangkat personal computer (PC) atau laptop yang terhubung dengan koneksi jaringan internet. ${ }^{10}$

\section{Evaluasi pembelajaran}

Pada dasarnya Evaluasi memiliki memiliki arti suatu kegiatan untuk memberi nilai atau pertimbangan yang sesuai dengan kriteria yang telah ditentukan untuk mendapatkan hasil evaluasi secara objektiv dan akurat dengan hasil yang berupa informasi kuantitatif ataupun kualitatif. ${ }^{11}$

Undang-undang nomor 20 tahun 2003 pasal 39 ayat 2 tentang sistem pendidikan nasional menyatakan bahwa pendidik adalah tenaga professional yang bertugas merencanakan dan melaksanakan proses pembelajaran,menilai hasil pembelajaran,serta melakukan penelitian dan pengabdian kepada masyarakat terutama bagi pendidik. Evaluasi pembelajaran merupakan satu kompetensi professional seorang pendidik. ${ }^{12}$

Bentuk-bentuk Evaluasi Pembelajaran secara Umum terbagi menjadi 2 yaitu berupa

Tes Subjektik dan Tes Objektif. Berikut penjelasanya:

a. Tes Tertulis berbentuk Uraian (Essay)

${ }^{9}$ Untung Rahardja, Ninda Lutfiani, and Moch Sandi Alpansuri, "Pemanfaatan Google Formulir Sebagai Sistem Pendaftaran Anggota Pada Website Aptisi.or.id,” SISFOTENIKA 8, no. 2 (July 30, 2018): 128, https://doi.org/10.30700/jst.v8i2.401.

10 Sriharnani, "Efektivitas pembelajaran Daring di masa Pandemic Covid19”. http://bdkjakarta.kemenag.go.id diakses pada 2 agustus 2020.

${ }^{11}$ Kuntum Annisa Imania and Siti Khusnul Bariah, "Rancangan Pengembangan Instrumen Penilaian Pembelajaran Berbasis Daring,” JURNAL PETIK 5, no. 1 (April 2, 2019): 31-47, https://doi.org/10.31980/jpetik.v5i1.445.

12 Asrul, Rusydi Ananda, dan Rosnita, Evaluasi pembelajaran (Bandung: PT. cipta pustaka media, 2015) hal.6. 
Tes Subjektif ini sering kita kenal dengan istilah Tes Essay atau Essay Examination. yaitu Tes yang dilakukan berbentuk sebuah pertanyaan tertulis, yang jawabanya berupa penjelasan atau kalimat panjang. Dan sering digunakan oleh para guru disekolah dari dahulu hingga saat ini. Biasanya dilakukan dengan lima pertanyaan atau lebih.

b. Tes Hasil Belajar Bentuk Objektif

Tes Objektif disebut dengan istilah Tes dikotomi (Dichotomously scored item) karena pertanyaan yang jawabanya hanya bisa dipilih Benar atau Salah kemudian setiap jawaban memiliki rentang skor 1 atau 0. Terdapat beberapa jenis tes bentuk Objektif, misalnya: bentuk melengkapi (Completion test), Pilihan ganda (multiple choise), menjodohkan (matching), bentuk pilihan benar-salah (true false), test objektik bentuk isian (fill in). ${ }^{13}$

Dalam proses pembelajaran ketika materi yang sudah dijelaskan oleh guru maka disetiap akhir materi atau semester akan diberlakukanya evaluasi pembelajaran yang dilakukan oleh guru mata pelajaran masing-masing. Menurut Hanna: “Assessment is the of collecting, interpreting, and shyntesizing information to aid in decision making. Assesment synonymous with measurement plus observation. It concerns drawing inferences from these data sources. Assesment merupakan proses pengumpulan, interpretasi, dan sintesis informasi untuk pengambilan keputusan. Pengambilan keputusan dalam Assesment dilakukan berdasarkan data yang diperoleh dari hasil pengukuran (data kuantitatif) dipadu dengan data kualitatif yang diperoleh dari hasil pengamatan. $^{14}$

Dalam buku measurement and evaluation in education and psychology (William A. mohrens: 1984) menjelaskan bahwa evaluasi pembelajaran dapat dilakukan dengan tes, meuserement, evaluation,dan Assesment. Dengan definisi sebagai berikut:

${ }^{14}$ Hanna,G.s.(1993) Better teaching trought better measurement. New York. ”panduan penjamin mutu proses pembelajaran Daring UMY”, yogyakarta Dikutip kembali pada 6 agustus 2020 
1) Tes yaitu evaluasi pembelajaran dengan membuat dan mengajukan sebuah pertanyaan yang harus dijawab. dan hasilnya dapat berupa ukuran nilai(angka).

2) Measurement yaitu evaluasi pembelajaran dengan melakukan observasi skala rating yang dapat menghasilkan informasi dalam bentuk skor.

3) Evaluasi yaitu proses penggambaran dan penyempurnaan informasi yang akan menjadi cara alternative.karena evaluasi mencakup seluruh penilaian.

4) Assesment adalah penilaian karakter dari seseorang seperti kemampuan akademik, kejujuran, kemampuan untuk mengejar dan sebagainya. $^{15}$

Dengan beberapa cara diatas proses evaluasi pembelajaran dapat dilakukan untuk mengukur dan menilai hasil dari proses pembelajaran. ${ }^{16}$ Evaluasi yang dimaksud dalam penelitian ini adalah evaluasi pembelajaran berupa Test hasil belajar berbentuk objektif (Dichotomously scored item) yang penggunaanya berupa pertanyaan berdasarkan objektif dengan menggunakan Google Form docs.

\section{Proses Evaluasi Dalam Pendidikan}

Diagram proses Evaluasi pembelajaran maka akan memiliki perubahan atau transformasi sebagai berikut:

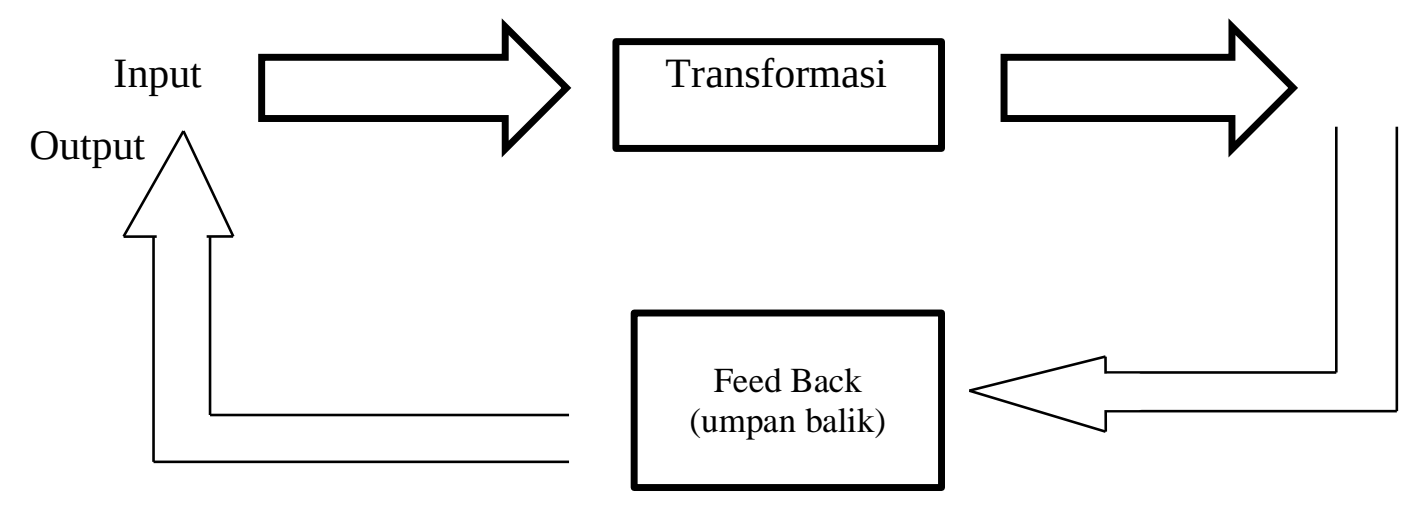

Gambar I: Proses Evaluasi Pendidikan.

- Input: adalah bahan mentah yang dimasukan ke dalam transformasi, dalam dunia pendidikan. Yang dimaksud dengan bahan mentah ialah calon peserta

${ }^{15}$ Imania and Bariah, "RANCANGAN PENGEMBANGAN INSTRUMEN PENILAIAN PEMBELAJARAN BERBASIS DARING.”

${ }^{16}$ Imam Gunawan, “EVALUASI PROGRAM PEMBELAJARAN,” n.d., 13. 
yang baru akan memasuki sekolah. Sebelum memasuki sekolah calon peserta didik dinilai kempuanya terlebih dahulu. Dengan adanya tes tersebut maka peserta didik akan mudah ditetapkan sesuai dengan kemampuanya.

- Output: adalah bahan jadi yang dihasilkan oleh transformasi. yakni peserta didik lulusan sekolah yang bersangkutan dapat menentukan apakah peserta didik berhak lulus atau tidak.

- Transformasi: adalah mesin yang bertugas mengubah bahan mentah menjadi bahan jadi. Sekolah sebagai alat tranformasi yang memiliki beberapa mesin yang dapat menunjang proses keberhasilanya tinggi atau rendah. Unsur- unsur tranformasi yang berperan di dalamnya ialah: Guru, metode pengajaran dan system evaluasi, sarana penunjang, system adminitrasi.

- $\quad{ }^{17}$ Feedback (umpan balik) : adalah segala informasi baik yang menyangkut output atau transformasi. ${ }^{18}$

Tujuan Evaluasi pembelajaran adalah untuk mengetahui kefektifan dan efisiensi sistem pembelajaran secara luas meliputi: Tujuan, materi, metode, media, sumber belajar, lingkungan dan sistem penilaian. Menurut Chittenden mengklasifikasikan tujuan evaluasi (assessment purpose) menjadi empat cakupan diantaranya yakni: keeping-track, checking-up, finding-out, summingup. Ke empat tujuan tersebut oleh Arifin diuraikan sebagai berikut:

1. Keeping track adalah guru dengan menulusuri dan melacak proses belajar peserta didik sesuai dengan rencana pelaksanaan pembelajaran yang sudah ditetapkan. Yang dimana guru mengumpulkan data dan informasi dalam kurun waktu tertentu sehingga memperoleh hasil berupa gambaran tentang pencapaian pembelajaran.

2. Checking up adalah mengecek ketercapaian pembelajaran peserta didik dan kekurangan - kekurangan peserta didik dalam mengikuti proses pembelajaran. Dengan ini guru melakukan penilaian guna mengetahui

17 Pitri Wulandari and Husnul Khotimah, "Google Form Sebagai Alternatif Evaluasi Pembelajaran Di Sman 2 Kota Tangerang” 2 (2019): 5.

18 Asrul, Rusydi Ananda, dan Rosnita, Evaluasi Pembelajaran (Medan : Ciptapustaka Media 2015) hal. 6 
sampai mana materi yang dikuasai oleh peserta didik selama mengikuti kegiatan belajar dan mengajar.

3. Finding out adalah mencari, menemukan, dan mendeteksi kekurangan atau kelemahan peserta didik dalam mengikuti proses pembelajaran.

4. Summing up adalah menyimpulkan tingkat pemahaman peserta didik dalam menguasai terhadap kompetensi yang telah ditetapkan. Dengan ini guru dapat menyimpulkan hasilnya dan dapat menjadi sumber data yang valid dalam penyusunan laporan pencapaian kompetensi pembelajaran. ${ }^{19}$

Evaluasi pembelajaran perlu upaya dalam peningkatan kualitas program pembelajaran dengan keseluruhan. ${ }^{20}$ Upaya peningkatan kualitas program pembelajaran membutuhkan informasi dari hasil evaluasi terhadap kualitas proses pembelajaran sebelumnya. Dengan begitu, untuk dapat melakukan pembaharuan ke berlangsungan program pendidikan, termasuk di dalamnya ialah program pembelajaran kegiatan evaluasi terhadap program yang sedang maupun telah berjalan sebelumnya perlu dilakukan dengan baik. ${ }^{21}$

Dengan demikian fungsi penilaian dalam proses belajar dan mengajar memiliki manfaat yang ganda, yakni bagi siswa dan guru. Penilaian hasil belajar dapat dilaksanakan dalam 2 tahap:

1. Tahap jangka pendek, yakni penilaian yang dilaksanakan oleh guru pada akhir proses belajar - mengajar. Penialaian ini disebut dengan penilaian formatif.

2. Tahap jangka panjang, yakni penilaian yang dilakukan setalah proses belajar-mengajar telah berlangsung beberapa kali atau telah menempuh waktu tertentu misalnya penilaian tengah semester (PTS) atau penilaian akhir semester (PAS). Penilaian ini bersifat sumatif. ${ }^{22}$

${ }^{19}$ Elis Ratna Wulan dan A.Rusdiana. Evaluasi Pembelajaran (Bandung : Pustaka Setia 2017) hal. 27

${ }^{20}$ agustanico Dwi Muryadi, “Model Evaluasi Program Dalam Penelitian Evaluasi,” 2017, 16.

${ }^{21}$ ahriyani Maidin, "Efektivitas Evaluasi Pembelajaran Akidah Akhlak Terhadap Prestasi Belajar Peserta Didik Di Madrasah Ibtidaiyah Ddi Amparita Kecamatan Tellu Limpoe Kab.Sidrap.” 7, no. 1 (2019): 14.

${ }^{22}$ Mila Faila Shofa, “Inovasi Pembelajaran pada Pendidikan Anak Usia Dini di Masa Pandemi Covid-19” 5 (2020): 12. 
Kedua proses evaluasi tersebut sangat penting digunakan, karena evaluasi untuk melihat prestasi siswa dapat digunakan dengan evaluasi formatif dan sumatif. Seorang guru yang akan melakukan penilaian maka hal-hal yang ditempuh ialah menetapkan sasaran objek penilaian.

Objek sasaran pokok dalam penialaian ialah: ${ }^{23}$

1. Segi tingkah laku yakni menyangkut sikap, minat, perhatian, ketrampilan siswa.

2. Segi isi pendidikan yakni penguasaan materi pembelajaran yang sudah diberikan oleh guru.

3. Segi menyangkut proses belajar- mengajar.

Ketiga sasaran pokok tersebut harus dievaluasi secara menyeluruh, yakni tidak hanya menilai dari segi tigkah laku saja akan tetapi ketika peserta didik melakukan proses pembelajaran dengan secara adil. Guru tidak harus memilih satu model penilaian saja, akan tetapi untuk mengetahui valid atau tidaknya hasil evaluasi pembelajaran harus melakukan banyak model. Seperti: Pertama, mearsurement ialah model yang menggunakan pengukuran kuantitatif yang didalamnya menilai dari tingkah laku, membandingkan dua kelompok atau lebih. Model penilaian mearsurement memiliki keterbatasan dalam aspek penilaian. Kedua, Congruence ialah model penilaian yang menggunakan penilaian hasil belajar dari pengetahuan, keterampilan dan sikap. Tidak membatasi pada alat penilaian yang digunakan dalam pengevaluasian. Ketiga, kontribusi congruence ialah dengan membandingkan antara tujuan yang harus dicapai dengan hasil belajar siswa. Yang hasilnya mampu mengetahui mana bagian mana yang belum tercapai dalam tujuan pembelajaran dan mana yang sudah tercapai. Keempat, system model ialah melakukan penilaian pada system model menilai atau mengukur kemampuan siswa yang mengacu pada system. Kelima, illuminative model ialah penilaian yang dilakukan dalam jangka pendek agar informasi yang didapat dan digunakan tepat pada waktunya.

${ }^{23}$ Elis Ratna Wulan dan A.Rusdiana. Evaluasi pembelajaran dengan pendekatan kurikulum 2013 (Bandung: Media Pustaka 2014) hal. 33. 
Namun dalam proses penilaianya tidak terstruktur langkah-langkahnya. ${ }^{24}$

Diantara kelima model penilaian tersebut memiliki kelebihan dan kekurangan. Jadi alangkah baiknya dalam proses evaluasi pembelajaran tidak hanya menggunakan satu model setidaknya dua model evaluasi pembelajaran. Dari sisi teknis memang tidak ada hal yang sulit untuk menerapkan model evaluasi pembelajaran berbasis Daring. Namun ketika guru memberikan tugas kepada murid dengan jangka waktu yang telah ditetapkan, maka ke khawatiran guru adalah kepada murid yang mendapatkan pendampingan yang ekstra sehingga menimbulkan kesan ragu bagi guru. ${ }^{25}$

\section{Metode Penelitian}

Pendekatan dalam penelitian ini adalah pendekatan kualititaf deskriptif. Adapun tehnik pengumpulan data menggunakan observasi, interview, dan dokumentasi. Tehnik analisa data yang digunakan adalah Reduksi data (Data Reduction), Penyajian data (Data Display), penarikan simpulan dan verifikasi ${ }^{26}$ Penelitian ini dilakukan disebuah Sekolah atau Lembaga pendidikan di jenjang Sekolah Dasar adalah Sekolah Dasar Islam Terpadu (SD IT) Baitul Muslim yang terletak di Jl.Ir.H. Juanda Labuhan Ratu, Labuhan Ratu Satu, Kec. Way Jepara, Kab. Lampung Timur Prov. Lampung.

Dalam penelitian ini data utama yang akan diperoleh oleh peneliti adalah: hasil wawancara (interview) dengan kepala sekolah, waka kurikulum, wali kelas serta guru mata pelajaran. Kemudian data sekunder di peroleh penelitian ini adalah berupa informasi dokumen-dokumen sekolah seperti profil sekolah, laporan hasil belajar siswa dan dokumen-dokumen lainya yang berkaitan dengan penelitian ini serta kepustakaan seperti berupa buku-buku ataupun jurnal-jurnal ilmiah, dan artikel- artikel yang ada kaitanya dengan

${ }^{24}$ Feri Tirtoni. Pembelajaran Terpadu di Sekolah Dasar (Sidoarjo: Umsida press 2018) hal. 200.

25 Syahruddin Damanik and Muhammad Zuhdi, “Model Evaluasi Pembelajaran Aud Berbasis Daring Di Ra Nurun Namirah Medan Marelan (Studi Kasus Selama Masa Pandemi Covid19),” no. 1 (2020): 18. hal.170

${ }^{26}$ Hardani.et .all. Metode Penelitian Kualitatif \& Kuantitatif. (CV Pustaka Ilmu: 2020) 
penelitian ini, serta penggunaan Google form dalam meningkatkan efektivitas evaluasi pembelajaran daring siswa pada musim covid19 di SD IT Baitul Muslim way Jepara.

Sesuai dengan penelitian ini yakni pendekatan kualitatif maka dalam penelitian ini menggunakan wawancara mendalam, studi dokumentasi, dan observasi pertisipasi. ${ }^{27}$

1. Wawancara semistruktural (Semistructure Interview)

Sesuai dengan instrument penelitian yang telah dipaparkan, maka informan pertama dalam penelitian ini adalah: Kepala SD IT Baitul Muslim Way Jepara, Wali Kelas, Guru Mata pelajaran, dan Guru pendamping. Hal-hal yang ditanyakan dalam interview meliputi:

a. Mengetahui kelebihan dan kekurangan penggunaan Google Form dalam evaluasi pembelajaran pada masa pandemic covid19?

b. Mendeskripsikan bentuk/hasil penggunaan Google Form di SD IT Baitul muslim Way Jepara?

c. Mengetahui tingkat efektivitas evaluasi pembelajaran daring dengan menggunakan Google Form?

\section{Observasi Partisipatif (Participant Observation)}

Dalam penelitian kali ini peneliti akan melaksanakan observasi tidak terstruktur, yaitu observasi yang tidak diperisapkan secara sistematis tentang apa yang akan diobservasi oleh peneliti, dan tidak menggunakan instrument yang telah baku namun berupa rambu-rambu pengamatan.

Dengan begini peneliti akan mendalami kehidupan atau mengamati dalam setiap proses penggunaan google form dalam evaluasi pembelajaran daring pada masa pandemic covid19 di SD IT Baitul Muslim Way jepara. Agar tidak mengganggu objek dalam pengamatan peneliti, maka pencatatan merupakan dilemma dilakukan. Bagian-bagian yang akan diamati dalam penelitian secara judul besarnya adalah:

\footnotetext{
${ }^{27}$ Junaidah "Jurnal Penelitian Pendidikan Agama Islam UIN Malang”, Penguatan Pendidikan Agama Islam di tingkat SLTP. vol.2 no.01 (2014). 79
} 
a. Keadaan fisik meliputi: situasi dan kondisi lingkungan sekolah, sarana dan prasarana yang menunjang proses kegiatan pembelajaran.

b. Kegiatan pembelajaran meliputi: persiapan sebelum pembelajaran dimulai, media yang digunakan dalam pembelajaran daring, dan evaluasi harian, tengah semester, akhir semester.

c. Kegiatan lainya: meeting lewat via zoom, rapat dengan protokol kesehatan dan kegiatan lainya baik daring maupun luring.

\section{Hasil Penelitian}

\section{a. Kelebihan dan Kekurangan Penggunaan Google Form dalam Evaluasi} Pembelajaran Pada Masa Pendemi Covid19 di SD IT Baitul Muslim Way Jepara

Dalam proses pembelajaran, siswa SD IT Baitul Muslim melakukan pembelajaran jarak jauh dengan media Whatsapp, Zoom, dan Telepon seluler. namun saat evaluasi pembelajaran tiba baik evaluasi harian, tengah semester, dan akhir semester SD IT BM menggunakan Google Form. Aplikasi dari Google tersebut sangat mudah diakses oleh siapapun dengan syarat memiliki akun g.mail.com. ${ }^{28}$ Semaraknya penggunaan Google form dalam masa pandemic saat ini, ada banyak kelebihan dan kekurangan dalam penggunaan aplikasi tersebut. Kelebihan dari penggunaan aplikasi Google form adalah :

a. Aplikasi yang sangat mudah digunakan baik dalam pembuatan maupun pemakaianya. $^{29}$

b. Gratis dapat menikmati layana Google Form secara gratis, tidak perlu membuang-buang uang untuk membeli aplikasi maupun layanan pembuatan formulir.

c. Programnya ringan tidak seperti zoom dan Microsoft Team yang sangat membutuhkan akses jaringan internet yang harus memadai.

d. Dapat dibagikan dengan mudah yang mana dapat disebar melalui platform.

${ }^{28}$ Wulandari and Khotimah, "Google Form Sebagai Alternatif Evaluasi Pembelajaran Di Sman 2 Kota Tangerang.”

${ }^{29}$ Mahyudin Ritonga et al., "Sosialisasi Pembuatan Soal Melalui Google Form Dalam Meningkatkan Kompetensi Guru Pai,” BERNAS: Jurnal Pengabdian Kepada Masyarakat 1, no. 4 (October 1, 2020): 347-54, https://doi.org/10.31949/jb.v1i4.456. 
e. Memiliki fitur Spreadsheets.yang dapat melihat tanggapan/respon survei yang telah di sebar keberbagai responden dengan tampilan formulir yang sangat rapi dan otomatis. ${ }^{30}$

Berdasarkan hal tersebut guru dapat mengolah soal-soal evaluasi pembelajaran dengan baik, sebelum diberlakukanya penggunaan Google Form dalam evaluasi pembelajaran Kepala SD IT Baitul Muslim Way Jepara terlebih dahulu melakukan responden angket untuk persetujuan penggunaan Google Form dalam kegiatan evaluasi pembelajaran daring tersebut. Sedangkan kekurangan Google Form diantaranya ialah:

1. Tidak dapat digunakan untuk ruang diskusi online.

2. Tidak dapat digunakan untuk equation dengan secara langsung, yakni simbol-simbol matematik. dan fitur ini yang tidak dimiliki oleh Google Form.

3. Desain yang terbatas

4. Pilihan ekspor yang terbatas

5. Tidak adanya notifikasi $e$-mail ketika respon telah masuk

6. Tidak ada riwayat pengeditan ${ }^{31}$

Berdasarkan data di atas, penggunaan Google form di SD IT Baitul Muslim Way Jepara hanya digunakan pada saat evaluasi pembelajaran daring, mengingat ada banyak kekurangan dalam fitur Google Form, Namun sebelum diberlakukanya evaluasi daring, pihak sekolah mensosialisasikan kepada wali murid bahwa evaluasi daring akan dilakukan dengan menggunakan Google Form. Pada sisi yang lain karena banyak dari wali murid yang notabennya seorang pekerja, maka Google Form ini menjadi salah satu alternatife bagi sekolah untuk tetap melakukan kegiatan evaluasi pembelajaran berbasis daring.

\section{b. Hasil Penggunaan Google Form di SDIT Baitul Muslim}

Google form merupakan salah satu aplikasi berupa lembar kerja yang berbentuk formulir yang dapat diaplikasikan dengan menggunakan alamat akun G-mail pribadi. Bentuk penyimpananya berupa Google Drive dan aplikasi lainya

30 Sarifah Farah Fadhilah "Kelebihan dan Kekurangan Google Form". http://nesabamedia.com . diakses pada 10 oktober 2020

${ }^{31}$ Andri Anugrahana, "Hambatan, Solusi dan Harapan: Pembelajaran Daring Selama Masa Pandemi Covid-19 Oleh Guru Sekolah Dasar,” Jurnal Pendidikan dan Kebudayaan 10, no. 3 (n.d.): 8. 
berupa Google Sheet, Google Docs dan lain-lain.

Hasil dari Google Form dapat diunduh dengan menggunakan aplikasi Spreadsheet yang dimana aplikasi tersebut dapat menyimpan hasil respon berupa Ms. Excel. Dengan ini maka data yang sudah tersimpan kedalam Ms.Excel akan dengan mudah di akses oleh guru mata pelajaran dan wali kelas dalam proses pengolahan nilai akhir evaluasi. ${ }^{32}$

Dari hasil angket yang sudah disosialisasikan oleh wali kelas kepada wali murid bahwa Google Form mendapat respon yang sangat baik sehingga hasil observasi memiliki data sebagai sebagai berikut:

\begin{tabular}{|l|l|}
\hline Item penilaian & presentase \\
\hline Kemudahan & $100 \%$ \\
\hline Kecepatan & $40 \%$ \\
\hline Kepraktisan & $60 \%$ \\
\hline Keefisienan & $60 \%$ \\
\hline
\end{tabular}

Berdasarkan tabel diatas dapat disimpulkan bahwa penggunaan Google form dalam pengevaluasian pembelajaran memiliki tingkat kemudahan sebesar 100\%, kecepatan 45\%, kepraktisan 60\% dan keefisienan 60\%. di karenakan letak geografis siswa dan sekolah memiliki jangkauan jaringan internet yang cukup bagus dan berjalan dengan baik. ${ }^{33}$

Adapun kendala dalam penyelenggaraan Penilaian Akhir, Penilaian Tengah Semester dan Akhir Semester diantaranya ialah wali kelas maupun guru mata pelajaran mengawasi keberlangsungan evaluasi tersebut. Seperti, apakah murid mengerjakan tugas semester tersebut dengan mandiri atau melakukan diskusi dengan orang tua murid. Akan tetapi, berdasarkan hasil angket bahwa pengerjaan evaluasi dilakukan mandiri oleh murid dan dalam pantauan wali murid.

${ }^{32}$ Bekti Mulatsih, “Penerapan Aplikasi Google Classroom, Google Form, Dan Quizizz Dalam Pembelajaran Kimia Di Masa Pandemi Covid-19” 5 (n.d.): 11.

33 Tria Mardiana and Arif Wiyat Purnanto, "Google Form Sebagai Alternatif Pembuatan Latihan Soal Evaluasi,” 2017, 6. 
Kelebihan yang ada pada Google Form guru merasa cukup terbantu baik dari sisi keuangan maupun tenaga. semua akan berjalan dengan baik apabila sarana dan prasarana sekolah yang memadai yakni jaringan internet, akun Gmail, dan elektronik (Handphone, tablet ataupun laptop) serta wali kelas maupun wali murid dapat dengan mudah melakukan evaluasi pembelajaran daring, Karena tidak harus menghadirkan siswa ke sekolah dan evaluasi pembelajaran seiring diberlakukanya pembelajaran jarak jauh (Daring). ${ }^{34}$

\section{c. Tingkat Ke-Efektivitasan Evaluasi Pembelajaran Daring dengan Menggunakan Google Form di SD IT Baitul Muslim Way Jepara}

Evaluasi pembelajaran yang dilakukan harus diperhatikan agar dapat berjalan dengan efektif. Terjadinya evaluasi pembelajaran yang efektif apabila dilakukan tidak hanya dengan satu jenis evaluasi saja, misalnya hanya mengandalkan tes lisan sedangkan guru tidak hanya mengambil satu jenis evaluasi saja melainkan beberapa jenis. Menurut Arifin (2012:29-30) untuk memperoleh hasil evaluasi yang lebih baik, perlu memperhatikan prinsip-prinsip evaluasi yakni ${ }^{35}$ :

a. Kontinuitas

Evaluasi tidak hanya dilakukan secara incidential, karena pembelajaran adalah suatu proses yang kontinu (berkelanjutan). Hasil evaluasi yang diperoleh digabungkan dengan hasil evaluasi yang lainya.

b. Komprehensif

Evaluasi yang megambil seluruh objek sebagai bahan evaluasi. Misalnya jika objek evaluasi adalah murid maka seluruh aspek kepribadian dievaluasi, baik dari segi kognitif, afektif, dan psikomotorik.

c. Objektivitas

Evaluasi pada bagian ini guru hanya melakukan evaluasi secara objektif semata dilakukan secara adil merata tanpa adanya kesenjangan social. Karena segi yang diamati adalah yang sesuai dengan keadaan murid,

${ }^{34}$ Fansuri Septiawan, "Efektivitas Penggunaan Google Form Dalam Pembelajaran Daring Pada Mata Pelajaran Pemeliharaan Mesin Sepeda Motor Di Smk Negeri 1 Koba” 7 (2020): 7.

35 Elis Ratna Wulan dan A.Rusdiana. Evaluasi Pembelajaran.(Bandung: Pustaka Setia.2014). hal. 37 
perasaan kemampuan murid, dan tanpa prasangka negatif, harus berdasarkan fakta.

d. Kooperatif

Dalam pengevaluasian ini maka guru melakukan kerja sama dengan seluruh pihak, yakni guru, kepala sekolah, murid dan orang tua murid.

e. Praktis

Evaluasi yang dilakukan dengan mudah oleh siapapun baik dari segi cara maupun jenisnya.

Berdasarkan penggalian data melalui interview kepada kepala sekolah dan wali kelas peneliti menyimpulkan bahwa evaluasi pembelajaran daring dengan menggunakan Google Form yang dilaksanakan oleh SDIT Baitul Muslim masih belum efektif. karena hanya tertuju pada satu jenis evaluasi yaitu berupa tes tertulis yang diaplikasikan kedalam Google docs.

Hal ini tentu perlu dilakukanya evaluasi yang bersifat kontinuitas, komprehensif, objektivitas, kooperatif, praktis. Karena dalam melakukan evaluasi pembelajaran tidak hanya mengandalkan satu jenis evaluasi pembelajaran lainya jika ingin mendapatkan hasil yang baik dalam evaluasi pembelajaran.

Optimalisasi dalam evaluasi ditujukan untuk guru dapat mengetahui tingkat perkembangan terhadap seluruh aspek pribadi murid, tidak hanya penilaian terhadap aspek penguasaan pengetahuan (kognitif) saja, melainkan dengan dilaksanakanya evaluasi pembelajaran maka seorang guru dapat memperoleh informasi yang valid tentang proses pembelajaran dan ketercapaian murid dalam mengikuti kegiatan belajar jarak jauh (Daring). ${ }^{36}$

\section{Kesimpulan}

Berdasarkan hasil pembahasan penelitian dapat disimpulkan bahwa penggunaan Google Form dalam evaluasi pembelajaran daring dapat dilakukan apabila sarana dan prasarana yang mendukung yaitu berupa jaringan internet yang

${ }^{36}$ Nunung Nuriyah, “Evaluasi Pembelajaran:,” no. 1 (2014): 14. 
terjangkau, letak geografis yang strategis, dan alat elektronik yang memadai seperti handpone, tablet, dan laptop. Hal-hal tersebut merupakan upaya SD IT Baitul Muslim untuk memutus mata rantai wabah Covid19 untuk tidak menghadirkan murid ke dalam area sekolah yang dikhawatirkan dapat menjadi sebab merebaknya penularan wabah covid19. Penggunaan aplikasi Google Form di SD IT Baitul Muslim mendapat respon yang baik dari guru dan wali murid karena salah satu kelebihan penggunaan Google Form ialah sangat mudah untuk diakses serta dapat meminimalisir biaya yang dibutuhkan pada saat evaluasi pembelajaran tatap muka (Luring). Evaluasi pembelajaran yang dilaksanakan adalah jenis evaluasi pembelajaran berupa tes yang bertujuan untuk mengukur dan menilai hasil belajar murid, terutama hasil belajar kognitif yang berkenaan dengan penguasaan bahan pelajaran. Namun, tes juga dapat digunakan untuk menilai hasil belajar di bidang afektif dan psikomotorik yang diaplikasikan ke dalam Google Form sehingga murid dapat dengan mudah melaksanakan evaluasi pembelajaran. Penggunaan Google Form dalam evaluasi pembelajaran belum sepenuhnya efektif untuk diterapkan apabila proses pembelajaran dilakukan dalam keadaan tatap muka (Luring) karena jenis evaluasi yang digunakan adalah berupa tes tertulis yang diaplikasikan kedalam fitur Google Docs. 


\section{DAFTAR PUSTAKA}

Anugrahana, Andri. "Hambatan, Solusi dan Harapan: Pembelajaran Daring Selama Masa Pandemi Covid-19 Oleh Guru Sekolah Dasar.” Jurnal Pendidikan dan Kebudayaan 10, no. 3 (n.d.): 8.

Asrul, Rusydi Ananda, Rosnita.2015. Evaluasi Pembelajaran. Bandung; Citapustaka Media (cet. II.).

Batubara, Hamdan Husein. "Penggunaan Google Form Sebagai Alat Penilaian Kinerja Dosen Di Prodi Pgmi Uniska Muhammad Arsyad Al Banjari,” n.d., 12.

Bulan, Sri, and Husniyatus Salamah Zainiyati. "Pembelajaran Online Berbasis Media Google Formulir dalam Tanggap Work From Home Masa Pandemi Covid-19 di Madrasah Ibtidaiyah Negeri (MIN) 1 Paser.” SYAMIL: Jurnal Pendidikan Agama Islam (Journal of Islamic Education) 8, no. 1 (June 10, 2020): 15-34. https://doi.org/10.21093/sy.v8i1.2300.

Damanik, Syahruddin, and Muhammad Zuhdi. "Model Evaluasi Pembelajaran Aud Berbasis Daring di RA Nurun Namirah Medan Marelan (Studi Kasus Selama Masa Pandemi Covid-19),” no. 1 (2020): 18.

Elis Ratnawulan, Rusdiana. Evaluasi Pembelajaran. Bandung; Pustaka Setia. (cet.II.).

Gunawan, Imam. “Evaluasi Program Pembelajaran,” n.d., 13.

Hamdan Husein Batubara.2016. Penggunaan Google Form Sebagai Alat Penilaian Kinerja Dosen di Prodi PGMI UNISKA Muhammad Arsyad Al Banjari. Jurnal Al-Bidayah (UNISKA) vol. 8 No.1 juni 2016.

Imania, Kuntum Annisa, and Siti Khusnul Bariah. "Rancangan Pengembangan Instrumen Penilaian Pembelajaran Berbasis Daring.” JURNAL PETIK 5, no. 1 (April 2, 2019): 31-47. https://doi.org/10.31980/jpetik.v5i1.445.

Irawati, Desrina Yusi, and Jonatan Jonatan. "Evaluasi Kualitas Pembelajaran Online Selama Pandemi Covid-19: Studi Kasus di Fakultas Teknik, Universitas Katolik Darma Cendika.” Jurnal Rekayasa Sistem Industri 9, no. 2 (July 27, 2020): 135-44. https://doi.org/10.26593/jrsi.v9i2.4014.135144.

Jariyah, Ita Ainun, and Esti Tyastirin. "Proses dan Kendala Pembelajaran Biologi di Masa Pandemi Covid-19: Analisis Respon Mahasiswa.” Jurnal Penelitian dan Pengkajian Ilmu Pendidikan: e-Saintika 4, no. 2 (July 8, 
2020): 183. https://doi.org/10.36312/e-saintika.v4i2.224.

Kurniasari, Asrilia, Fitroh Setyo Putro Pribowo, and Deni Adi Putra. “Analisis Efektivitas Pelaksanaan Belajar Dari Rumah (Bdr) Selama Pandemi Covid19” 6, no. 3 (2020): 8.

Maidin, Ahriyani. "Efektivitas Evaluasi Pembelajaran Akidah Akhlak Terhadap Prestasi Belajar Peserta Didik Di Madrasah Ibtidaiyah Ddi Amparita Kecamatan Tellu Limpoe Kab.Sidrap.” 7, no. 1 (2019): 14.

Mardiana, Tria, and Arif Wiyat Purnanto. "Google Form Sebagai Alternatif Pembuatan Latihan Soal Evaluasi,” 2017, 6.

Mulatsih, Bekti. "Penerapan Aplikasi Google Classroom, Google Form, Dan Quizizz Dalam Pembelajaran Kimia Di Masa Pandemi Covid-19” 5 (n.d.): 11 .

Muryadi, Agustanico Dwi. "Model Evaluasi Program Dalam Penelitian Evaluasi,” 2017, 16.

Neng Marlina Efendi. Revolusi Pembelajaran Berbasis Digital. Jurnal Pendidikan, Sosiologi dan Antropologi (UGM). Vol.2 No.2 September 2018.

Nuriyah, Nunung. “Evaluasi Pembelajaran:,” no. 1 (2014): 14.

Oktavian, Riskey, and Riantina Fitra Aldya. "Efektivitas Pembelajaran Daring Terintegrasi di Era Pendidikan 4.0.” Didaktis: Jurnal Pendidikan dan Ilmu Pengetahuan 20, no. 2 (May 12, 2020). https://doi.org/10.30651/didaktis.v20i2.4763.

Rahardja, Untung, Ninda Lutfiani, and Moch Sandi Alpansuri. "Pemanfaatan Google Formulir Sebagai Sistem Pendaftaran Anggota Pada Website Aptisi.or.id.” SISFOTENIKA 8, no. 2 (July 30, 2018): 128. https://doi.org/10.30700/jst.v8i2.401.

Ritonga, Mahyudin, Ahmad Lahmi, Rimelfi Rimelfi, Fathul Bahri, and Ilyas Tuangku Bagindo. "Sosialisasi Pembuatan Soal Melalui Google Form Dalam Meningkatkan Kompetensi Guru Pai.” BERNAS: Jurnal Pengabdian Kepada Masyarakat 1, no. 4 (October 1, 2020): 347-54. https://doi.org/10.31949/jb.v1i4.456.

Rizqon Halal Syah Aji. 2020. Dampak Covid19 pada Pendidikan di Indonesia: Sekolah,Keterampilan, dan Proses Pembelajaran. Jurnal Sosial\&Budaya Syar-I (UIN Syarif Hidayatullah Jakarta). Vol.7 No.5 April 2020.

Septiawan, Fansuri. "Efektivitas Penggunaan Google Form Dalam Pembelajaran Daring Pada Mata Pelajaran Pemeliharaan Mesin Sepeda Motor Di Smk 
Negeri 1 Koba” 7 (2020): 7.

Shofa, Mila Faila. “Inovasi Pembelajaran pada Pendidikan Anak Usia Dini di Masa Pandemi Covid-19” 5 (2020): 12.

Sugiyono. 2013 Metode Penelitian Kuantitatif, Kualitatif dan R\&D. Bandung; Alfabeta.

Sugiyono.2020. Metode Penelitian Kualitatif. Bandung; Alfabeta. (cet.III.).

Wulandari, Pitri, and Husnul Khotimah. "Google Form Sebagai Alternatif Evaluasi Pembelajaran Di Sman 2 Kota Tangerang” 2 (2019): 5. 
